\title{
PHYTOCHEMICAL IDENTIFICATION AND ANTIOXIDANT ACTIVITY OF PASSIFLORA FOETIDA FRUITS AND LEAVES EXTRACTS: A COMPARATIVE STUDY
}

\section{YOHANES TANDORO, PAINI SRI WIDYAWATI, TARSISIUS DWI WIBAWA BUDIANTA, GRACE SUMARGO}

Study Programme of Food Technology, Faculty of Agricultural Technology, Surabaya Widya Mandala Catholic University, Dinoyo Street Number 42-44 Surabaya 60265

Email: y.tandoro@gmail.com

Received: 19 Dec 2018, Revised and Accepted: 11 Apr 2020

\section{ABSTRACT}

Objective: The objective of this study was to compare the phytochemical composition and antioxidant activity of Passiflora foetida fruits and leaves extract.

Methods: The parameters observed in this study were phytochemical compounds including alkaloid, flavonoid, phenolic, sterol, triterpenoid, saponin, tannin, and cardiac glycoside, total phenolic content Folin Ciocalteu method is based on reduction of Folin Ciocalteu reagent in alkaline medium; the metal complex produced measured at $\lambda_{\text {max }} 760 \mathrm{~nm}$; total flavonoids content with $\mathrm{AlCl}_{3}$ Colorimetric method based on complex formation of $\mathrm{AlCl}_{3}$ and flavonoid content in alkaline medium, the $\mathrm{AlCl}_{3}$-flavonoid complex produced measured at $\lambda_{\text {max }}: 510 \mathrm{~nm}$; free radical DPPH scavenging activity; and ferric reducing power based on reduction of $\mathrm{Fe}^{3+}$ ion into $\mathrm{Fe}^{2+}$ ion that reacted with $\mathrm{FeCl}_{3}$ to form a ferric-ferrous complex that measured at $\lambda_{\max }: 700 \mathrm{~nm}$.

Results: Passiflora leaves extract has phytochemical compound such as alkaloids, phenolics, flavonoids, saponins, and cardiac glycosides, total phenol was $22.92 \pm 0.18 \mathrm{mg} \mathrm{GAE} / \mathrm{g}$ sample dry base, total flavonoid was $7.01 \pm 0.10 \mathrm{mg} \mathrm{CE} / \mathrm{g}$ sample dry base, DPPH scavenging activity was $2.77 \pm 0.02 \mathrm{mg} \mathrm{GAE} / \mathrm{g}$ sample dry base and ferric reducing power was $3.20 \pm 0.04 \mathrm{mg} \mathrm{GAE} / \mathrm{g}$ sample dry base meanwhile Passiflora fruits extract had phytochemical compounds such as alkaloid, phenolic, flavonoids, cardiac glycosides, total phenol was $6.53 \pm 1.02 \mathrm{mg} \mathrm{GAE} / \mathrm{g}$ sample dry base, total flavonoids were $1.56 \pm 0.27 \mathrm{mg} \mathrm{CE} / \mathrm{g}$ sample dry base, DPPH free radical scavenging activity was $1.00 \pm 0.15 \mathrm{mg}$ GAE/g sample dry base, and ferric reducing power was $1.12 \pm 0.17 \mathrm{mg} \mathrm{GAE} / \mathrm{g}$ sample dry base.

Conclusion: Passiflora leaves extract has higher total phenol, total flavonoid and antioxidant activity measured by DPPH scavenging activity and ferric reducing power value compared with Passiflora fruits extract.

Keywords: Passiflora fruits extract, Passiflora leaves extract, Antioxidant

(c) 2020 The Authors. Published by Innovare Academic Sciences Pvt Ltd. This is an open access article under the CC BY license (http://creativecommons.org/licenses/by/4.0/) DOI: http://dx.doi.org/10.22159/ijpps.2020v12i6.31505. Journal homepage: https://innovareacademics.in/journals/index.php/ijpps

\section{INTRODUCTION}

Passiflora foetida, usually called rambusa is a wild plant usually found in the tropical region and found creeping on another plant. Passiflora foetida can be eaten raw as lalapan or used as medicine to cure many diseases like fever, headache and asthma [1,2]. Passiflora foetida is grouped in the Passifloraceae family and generally grows in humid places like river and swamp [1]

Passiflora foetida can be used as a traditional medicine because it contains phytochemical compounds. The phytochemical compound in Passiflora foetida is an alkaloid, phenolic, glycoside, flavonoid and cyanogenic compound that can be used as an antioxidant [1] Passiflora foetida has many biological activities such as antiinflammation, antitumor, anticancer, antimicrobe and many pharmacological activities. [3]. Therefore it is necessary to conduct further research on Passiflora foetida leaves and fruits as a source of antioxidants. This research was conducted to compare the phytochemical compound and antioxidant activity of Passiflora foetida leaves and fruits extracts.

\section{MATERIALS AND METHODS}

\section{Plant material}

Leaves and fruits of Passiflora foetida were collected from the Mangrove forest region, Wonorejo, Surabaya. Leaves and fruits of Passiflora foetida used for this study has a different classification for Passiflora foetida leaves were green color, has a length of $\pm 9 \mathrm{~cm}$ and width $\pm 10 \mathrm{~cm}$, intact, and not perforated while the classification for Passiflora foetida fruits was green color, has a diameter of $\pm 1.5 \mathrm{~cm}$, intact, and flat skin surface. The plant was authenticated in the Herbarium of Biology and Food Industry Microbiology Laboratory at the Department of Food Technology, Agricultural Technology Faculty, the Widya Mandala Catholic University of Surabaya with voucher specimen no FTP-UKWMS-0002 for future reference.

\section{Chemical reagent}

Aquabidest, aquadest, sodium hydroxide, chloroform, ammonia sulfuric acid, mercury chloride, potassium iodide, iodine, methanol, ethanol, ether, acetic acid, magnesium powder, hydrochloric acid, namyl alcohol, ferric chloride, copper (II) sulfate, potassium sodium tartrate, gallic acid, Folin Ciocalteu, sodium carbonate, (+)-catechins, sodium nitrite, aluminum chloride, DPPH, sodium phosphate monobasic, sodium phosphate dibasic, potassium ferricyanide, chloroacetic acid.

\section{Passiflora foetida leaves extraction}

Passiflora foetida leaves that have been collected were dried at ambient temperature, ground and sieved with 28 mesh size. The dried flour of Passiflora foetida leaves was measured moisture content. For the extraction process, 2 g of Passiflora foetida leaves dried flour was packed in a tea bag and extracted with $100 \mathrm{ml}$ of hot water $\left(95^{\circ} \mathrm{C}\right)$. Parameters were analyzed, including phytochemical content, total phenol, total flavonoid, DPPH free radical scavenging activity, and ferric reducing power.

\section{Passiflora foetida fruits extraction}

Passiflora foetida fruits that have been collected were weighted 250 $\mathrm{g}$ and crushed with the addition of aqua dest (fruit: aquadest $=1: 3$ ) The mixture of crushed fruit was macerated with a magnetic stirrer at ambient temperature for $3 \mathrm{~h}$. The mixture was filtered and the filtrate was dried with a freeze dryer for $\pm 72 \mathrm{~h}$. Dried powder of 
Passiflora foetida fruits extracts weighed $1 \mathrm{~g}$ and dissolved in $50 \mathrm{ml}$ water. Parameters were analyzed, including phytochemical content, total phenol, total flavonoid, ferric reducing power, and DPPH free radical scavenging activity.

\section{Moisture content}

Moisture content of Passiflora foetida dried leaves flour and fruit are determined with the thermogravimetric method [4]. One gram of samples is measured with the oven at $105^{\circ} \mathrm{C}$. The difference weight between before and after heating was the moisture content of the sample.

\section{Yield analysis}

Yield analysis of Passiflora foetida fruits was measured with the comparison between the weight of dried fruit extract and initial fresh fruit weight (\% w/w dry base). The yield of Passiflora foetida fruits was used to determine the concentration of the antioxidant compound in fresh fruits.

\section{Phytochemical identification}

Phytochemical identification was done to determine phytochemical content in samples such as alkaloid, flavonoid, phenolic, sterol, triterpenoid, saponin, tannin, and cardiac glycoside in Passiflora foetida leaves and fruits extracts [5].

\section{Total phenol analysis}

Total phenol analysis was determined by spectrometry method [6]. $100 \mu \mathrm{l}$ sample was added with $1 \mathrm{ml}$ Folin Ciocalteu $10 \%$ and $2 \mathrm{ml}$ Sodium Carbonate $7.5 \%$. The mixture was added with water in a 10 $\mathrm{ml}$ volumetric flask and shook. The solution was incubated at ambient temperature for $30 \mathrm{~min}$ and the absorbance of the sample was measured at $\lambda 760 \mathrm{~nm}$. The total phenolic content of the sample was stated by gallic acid equivalence (GAE)/g sample dry base.

\section{Total flavonoid analysis}

Total flavonoid analysis was determined by the $\mathrm{AlCl}_{3}$ colorimetry method [7]. $200 \mu \mathrm{l}$ sample was added with $0.3 \mathrm{ml} \mathrm{NaNO}{ }_{2} 5 \%$ (b/v), $0.3 \mathrm{ml} \mathrm{AlCl}{ }_{3} 10 \%(\mathrm{~b} / \mathrm{v})$, and $2 \mathrm{ml} \mathrm{NaOH} 1 \mathrm{M}$ in $10 \mathrm{ml}$ volumetric flask. The mixture shook and diluted with water until volume $10 \mathrm{ml}$. The absorbance of the sample was measured at $\lambda 510 \mathrm{~nm}$. Total flavonoid content of the sample was stated by catechin equivalence (CE)/g sample dry base

\section{DPPH radical scavenging activity}

Passiflora foetida leaves and fruits extract antioxidant activity was measured by spectrophotometer [8]. $3 \mathrm{ml}$ of DPPH solution (4 $\mathrm{mg} / 100 \mathrm{ml}$ methanol) was added to $100 \mu \mathrm{l}$ sample in a test tube and diluted until $5 \mathrm{ml}$. The mixture was incubated in ambient temperature for $30 \mathrm{~min}$. The absorbance of the sample was measured at $\lambda 517 \mathrm{~nm}$. DPPH radical scavenging activity was stated as $\%$ inhibition using the equation:

$$
\% \text { inhibition: } \frac{A b s_{\mathrm{t}=0}-A b s_{\mathrm{t}=s 0}}{A b s_{\mathrm{t}=0}} \times 100 \%
$$

Abst $=0=$ Control absorbance

$\mathrm{Abs}_{\mathrm{t}=30}=$ Sample absorbance

\section{Ferric reducing power}

Ferric reducing power of Passiflora foetida leaves and fruits extracts were measured by spectrophotometer [9]. $200 \mu \mathrm{l}$ sample mixed $2.5 \mathrm{ml}$ phosphate buffer (pH 6.6) and $2.5 \mathrm{ml}$ potassium ferricyanide $1 \%$ and incubated at $50^{\circ} \mathrm{C}$ for $20 \mathrm{~min} .2 .5 \mathrm{ml}$ chlorogenic acid $10 \%$ was added to the solution and the mixture centrifuged at $3000 \mathrm{rpm}$ for $10 \mathrm{~min} .2 .5 \mathrm{ml}$ of supernatant was added with $2.5 \mathrm{ml}$ aquabidest and $0.5 \mathrm{ml}$ ferric chloride $0.1 \%$ and incubated for $10 \mathrm{~min}$. The absorbance of the sample was measured at $\lambda 700 \mathrm{~nm}$. High absorbance indicates an increased ferric reducing power. The ferric reducing power of the sample was stated as a gallic acid equivalence (GAE)/g sample dry base.

\section{RESULTS AND DISCUSSION}

Passiflora foetida dried leaves flour and fruits had moisture around $13.51 \pm 0.34 \%$ and $85.36 \pm 0.36 \%$, respectively. The yield obtained from fruits extraction with aqua dest was $8.81 \pm 1.36 \%$. Passiflora foetida leaves and fruits extracts contained phytochemical compounds that were shown in table 1 . Data-informed that both leaves and fruits extract contained alkaloid, flavonoid, phenolic compound and cardiac glycoside. The difference was saponin content in leaves extract that wasn't detected in fruit extract.

Tannin, terpenoid, and sterol weren't detected in both extracts. Terpenoid and sterol was nonpolar compound [10] and the solvent used to extract was aqua dest which is a polar solvent. Tannin is a water-soluble active compound that can be found in the plant. In this study, tannin wasn't detected in both extracts. A different result was obtained from [11] who found tannin in both extract and [12] found tannin in Passiflora leaves. The difference result was caused by a different place of plant growth that can influence the nutritional value and phytochemical content of plants [13].

Total phenol, Flavonoid, DPPH scavenging activity, and ferric reducing power shown in fig. 1, 2, 3 and 4, respectively. Total phenol and flavonoid of Passiflora leaves extract $(22.92 \pm 0.18 \mathrm{mg} \mathrm{GAE} / \mathrm{g}$ Sample dry base and $7.01 \pm 0.10 \mathrm{mg} \mathrm{CE} / \mathrm{g}$ Sample dry base respectively) was higher compared with Passiflora fruits extract (6.53 $\pm 1.02 \mathrm{mg}$ GAE/g Sample dry base and $1.56 \pm 0.27 \mathrm{mg}$ CE/g Sample dry base respectively). Consequently leaves extract of Passiflora leaves extract scavenging activity and reducing power was higher $(2.76 \pm 0.01$ and $3.20 \pm 0.04 \mathrm{mg}$ GAE/g Sample dry base respectively) than Passiflora fruits extract $(1.00 \pm 0.15$ and $1.12 \pm 0.17 \mathrm{mg} \mathrm{GAE} / \mathrm{g}$ Sample dry base respectively).

Table 1: Phytochemical compound in passiflora foetida leaves and fruits extracts

\begin{tabular}{|c|c|c|c|c|c|c|c|c|}
\hline Sample & Alkaloid & Flavonoid & Phenolic & Saponin & Tannin & $\begin{array}{l}\text { Cardiac } \\
\text { glycoside }\end{array}$ & Terpenoid & Sterol \\
\hline Leaf extract & + & + & + & + & - & + & - & - \\
\hline Fruit extract & + & + & + & - & - & + & - & - \\
\hline
\end{tabular}

Note: +detected based on color change,-not detected based on color change

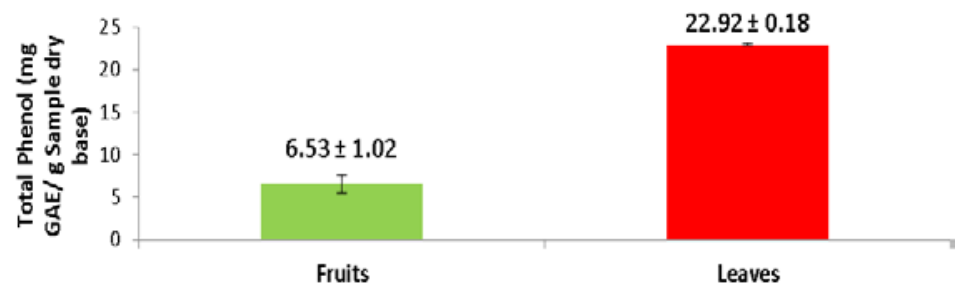

Fig. 1: Total phenol in passiflora leaves and fruits extracts, note: each sample was replicated 5 times with results for fruits and leaves respectively was $6.53 \pm 1.02$ and $22.92 \pm 0.18$ 


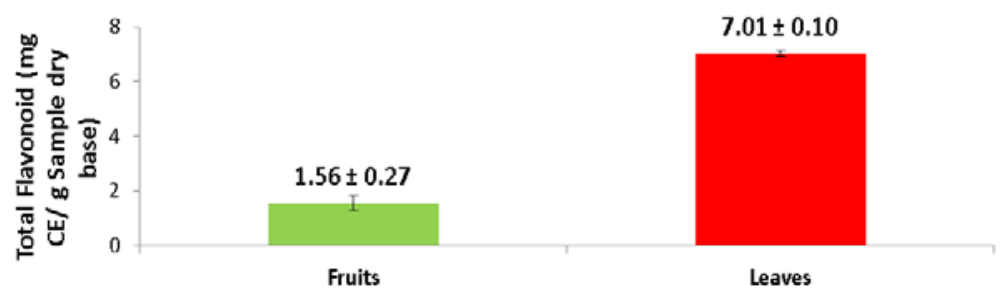

Fig. 2: Total flavonoid in passiflora leaves and fruits extract, note: each sample was replicated 5 times with results for fruits and leaves respectively was $1.56 \pm 0.27$ and $7.01 \pm 0.10$

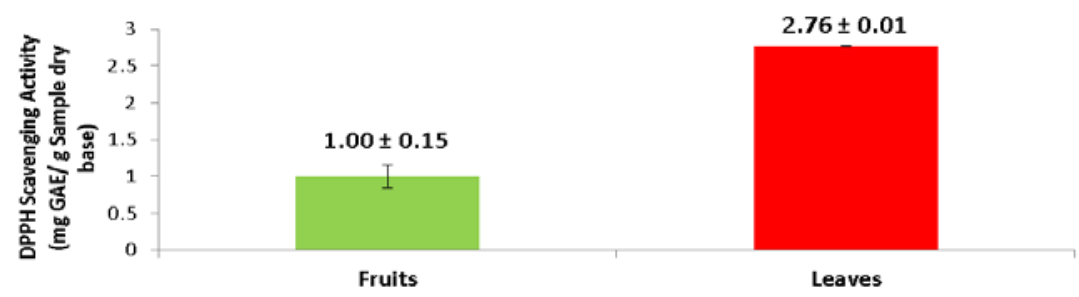

Fig. 3: DPPH scavenging activity in passiflora leaves and fruits extracts, Note: each sample was replicated 5 times with results for fruits and leaves respectively was $1.00 \pm 0.15$ and $2.76 \pm 0.01$

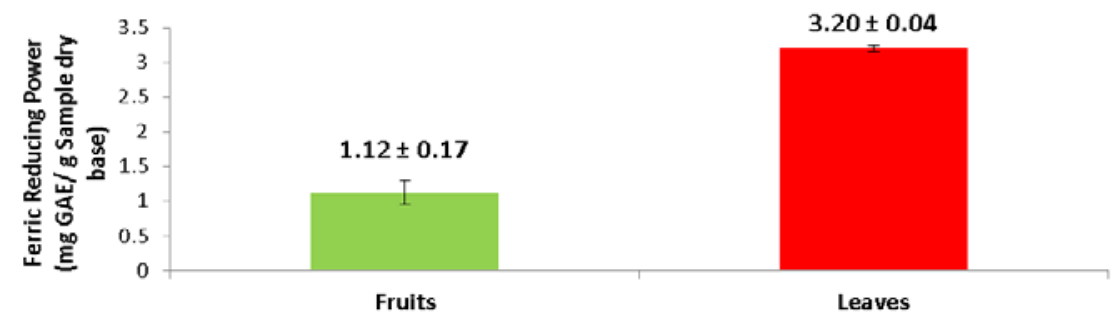

Fig. 4: Ferric reducing power in passiflora leaves and fruits extract, Note: each sample was replicated 5 times with results for fruits and leaves respectively was $1.12 \pm 0.17$ and $3.20 \pm 0.04$

Total phenolic content of determined by some factors like enzyme activity of Phenylalanine Ammonia-Lyase (PAL) and Chalcone Synthase (CHS) in plants [14] and the number of free hydroxyl group in the sample [15]. The formation of flavonoids is influenced by the action of CHS enzymes that form chalcone compounds which are subsequently isomerized by $\mathrm{CHI}$ enzyme (chalcone isomerase) into another flavonol compounds [16].

Total phenol and flavonoid from Passiflora leaves and fruits extracts were different because a different part of the plant has different functions and nutrition content. Leaves have a function for photosynthesis and place to storage nutrition [5] meanwhile fruit has the function to protect the seeds by surrounding it with flesh containing mineral, simple organic compound, and substrate and facilitate its dispersal [17].

Data in fig. 1 and 2 showed that flavonoid content in both extracts was too low compared to total phenolic content. $80 \%$ of the phenolic compound in the plant was flavonoid [3]. High results in total phenol assay correlated with the Folin-Ciocalteu method. Folin-Ciocalteu method wasn't a specific method to measure total phenol [18]. The presence of another reducing agent like aromatic amine, reducing sugar and ascorbic acid in a sample can increase the result of total phenol.

Antioxidant activity related to total phenol and flavonoid in Passiflora leaves and fruits extracts that can be measured as free radical scavenging activity and ferric reducing power. The measurement was based on the donation of a hydrogen atom or electron from the antioxidant compound to free radical. Total phenol and flavonoid were correlated with DPPH scavenging activity and ferric reducing power $[3,19,20,21]$. DPPH assay was based on the decolorization of DPPH free radical from purple into yellowish color in the presence of antioxidant compounds $[22,23]$. DPPH scavenging activity stated as inhibition rate that calculated from the difference of control and sample absorbance divided with control absorbance. Ferric reducing power was measured as a secondary antioxidant activity [24]. Ferric reducing power was measured based on the ability of an antioxidant compound to reduced ferric (III) iron ion to ferrous (II) iron ion that can be seen from the change of color from yellow to green-Prussian blue color [25]. Data showed that Passiflora leaves extract has higher DPPH free radical scavenging activity and ferric reducing power compared with fruit extract. This caused by a higher concentration of phenolic and flavonoid content in leaves extract. The higher concentration of the phenolic compound in the sample, the scavenging activity and ferric reducing power value will be increased [20].

\section{CONCLUSION}

The result obtained in this study showed that Passiflora leaves extract has higher total phenol, total flavonoid and antioxidant activity measured by DPPH scavenging activity and ferric reducing power value compared with Passiflora fruits extract.

\section{ACKNOWLEDGMENT}

The authors would like to thank the PPPG (Food and Nutrition Center) of Widya Mandala Catholic University in Surabaya for the financial support for this research.

\section{FUNDING}

Nil

\section{AUTHORS CONTRIBUTIONS}

All authors have equal contributions. 


\section{CONFLICTS OF INTERESTS}

Authors declare no conflicts of interest.

\section{REFERENCES}

1. Lim TK. Edible medicinal and non-medicinal plants. Fruits 2012;4:166-72.

2. Quattrocchi U. CRC world dictionary of medicinal and poisonous plants common names, scientific names, eponyms, synonyms and, etymology; 2012. p. 2803-4.

3. Widyawati PS, TDW Budianta, FA Kusuma, dan EL Wijaya. Difference of solvent polarity to phytochemical content and antioxidant activity of pluchea indicia less leaves extracts. Int J Pharmacogn Phytochem Res 2014;6:850-5.

4. Sudarmadji S. Prosedur analisa untuk bahan makanan dan pertanian; 2007. p. 67-9, 83, 99-100.

5. Harborne JB. Phytochemical methods. Chapman and Hall, London; 1973. p. 14-20.

6. Muntana N, S Prasong. Study on total phenolic contents and their antioxidant activities of thai white, red, and black rice bran extracts. Pak J Biol Sci 2010;13:170-4.

7. Kumar S, D Kumar, Manjusha, K Saroha, N Singh, B Vashishta. Antioxidant and free radical scavenging potential of Citrullus colocynthis (L.) schrad methanolic fruit extract. Acta Pharm 2008;58:215-20.

8. Sompong R, S Siebenhandl-Ehn, G Linsberger Martin, E Berghofer. Physicochemical and antioxidative properties of red and black rice varieties from Thailand, China and Sri Lanka. Food Chem 2011;124:132-40.

9. Park YS, SJ Kim, HI Chang. Isolation of anthocyanins from black rice (Heugjinjubyeo) and screening of its antioxidant activities. J Microbial Biotechnol J Microb Biotechnol 2008;36:55-60.

10. Patterson GW, WD Nes. Physiology and biochemistry of sterols; 1991.

11. George M. Qualitative and quantitative phytochemical analysis on the leaves and fruits of Passiflora foetida. Int J Pharm Sci Invent 2017;6:26-30.

12. Odewo SA, AO Agbeja, KA Olaifa, AP Ojo, SA Ogundana. Proximate and spectroscopic analysis of Passiflora Foetida L. Int J Sci Technol Res 2014;3:353-6.
13. Decoteau DR. Principles of plant science environmental factors and technology in growing plants; 2005. p. 89.

14. Cheynier V, G Comte, KM Davies, V Lattanzio, S Martens. Plant phenolics: recent advances on their biosynthesis, genetics, and ecophysiology. Plant Physiol Biochem 2013;72:1-20.

15. Widyawati PS, CH Wijaya, PS Hardjosworo, dan D Sajuthi. Pengaruh ekstraksi dan fraksinasi terhadap kemampuan menangkap radikal bebas DPPH (1,1-difenil-2-pikrilhidrazil) ekstrak dan fraksi daun beluntas (Pluchea indica Less). Seminar Rekayasa Kimia dan Proses; 2010. p. 1-7.

16. Ramawat KG, JM Merillon. Natural products phytochemistry, botany and metabolism of alkaloids, phenolics, and terpenes. Berlin: Springer; 2013.

17. Robinson R. Ed. Plant Sciences. New York: Macmillan Reference USA; 2001. p. 156-7.

18. Ainsworth EA, KM Gillespie. Estimation of total phenolic content and other oxidation substrates in plant tissues using a folin-ciocalteu reagent. Nat Protoc 2007;2:875-7.

19. Anesini C, GE Ferraro, R Filip. Total polyphenol content and antioxidant capacity of commercially available tea (Camellia sinensis) in Argentina. J Agric Food Chem 2008;56:9225-9.

20. Rorong JA, E Suryanto. Analisis fitokimia eceng gondok (Eichhornia crassipes) dan efeknya sebagai agen photoreduksi Fe+3. J Chem Prog 2010;3:33-41.

21. Widyawati PS, YDW Werdani, C Setiokusumo, A Kartikasari. In vitro antioxidant capacities and antidiabetic properties of pluchea leaves and green tea mixtures at various proportions. Int J Pharm Pharm Sci 2017; 9:203-8.

22. Aksoy L, E Kolay, Y Agilonu, Z Aslan, M Kargioglu. Free radical scavenging activity, total phenolic content, total antioxidant status, and total oxidant status of endemic Thermopsis turcica. Saudi J Biol Sci 2013;20:235-9.

23. Widyawati PS. Determination of antioxidant capacity in Pluchea Indica less leaves extract and its fractions. Int J Pharm Pharm Sci 2016;8:32-6.

24. Pokorny J, N Yanishlieva, M Gordon. Antioxidants in food practical applications; 2001. p. 10-7, 30-2.

25. Liu J, Wang C, Wang Z, Zhang C, Lu S, Liu J. The antioxidant and free-radical scavenging activities of extract and fractions from corn silk (Zea mays L.) and related flavone glycosides. Int Food Chem 2011;126:261-9. 